\title{
Monipuolinen kavalkadi hiljaisen tiedon käsitteen erilaisista käyttötavoista
}

Auli Toom, Jussi Onnismaa, Anneli Kajanto (toim.) (2008). Hiljainen tieto. Tietämistä, toimimista, taitavuutta. Aikuiskasvatuksen 47. vuosikirja. Julkaisijat: Kansanvalistusseura ja Aikuiskasvatuksen Tutkimusseura. Kustantaja: Kansanvalistusseura.

Aikuiskasvatuksen 47. vuosikirja vuodelta 2008 on nimeltään "Hiljainen tieto. Tietämistä, toimimista, taitavuutta”. Auli Toomin, Jussi Onnismaan ja Anneli Kajannon toimittama lähes 400 sivuinen teos käsittelee hiljaista tietoa 22 kirjoittajan voimin. Kirjoittajat ovat akateemisia taloustieteen, kasvatustieteen, yhteiskuntatieteiden, psykologian, filosofian ja hoitotieteen osaajia. Koossa on siis varsin monipuolinen joukko kirjoittajia ja tämä myös näkyy kirjan artikkelien sisällöissä, jotka käsittelevät hiljaisen tiedon ja tietämisen monimuotoisuutta, ilmenemistä, siirtämistä ja tunnistamista ja tunnustamista erilaisilla asiantuntijuuden ja organisaatioiden kentillä.
Auli Toomin kirjan avaava artikkeli "Hiljaista tietoa vai tietämistä. Näkökulmia hiljaisen tiedon käsitteen tarkasteluun" (3358) on monessa suhteessa kirjan kokonaisuuden kannalta tärkeä. Siinä määritellään hiljaisen tiedon ja tietämisen käsitteet ja kuvataan niiden historiaa (Polanyi, Wittgenstein, Ryle) sekä luodaan näkymä näiden käsitteiden monimuotoisuudesta ja tutkijoiden (mm. Rolf, Argyris \& Schön, Eraut, Westera, Kothagen, Niiniluoto) esittämistä lähikäsitteistä, kuten taitotieto, kompetenssi, kompetenssien kokonaisuus, toiminnan teoria ja know how.

Toom määrittelee hiljaisen tiedon produktina ja hiljaisen tietämisen prosessina. Hiljainen tie- to on kokemuksen kautta kasautunutta kontekstuaalista praktista osaamista ja taitoja sekä käsityksiä ja uskomuksia, jotka vaikuttavat ja näkyvät toiminnassa. Hiljainen tietäminen sen sijaan on hiljaista tietoa ilmentävä toiminnallinen prosessi, jossa toiminnan tarkoitus suuntaa toimintaa, johon vaikuttavat tilanteelliset vihjeet sekä pysyvämmät syvemmät tekijät henkilön tietorakenteissa. Toom pitäytyy analyyttisesti hyödyllisessä näkemyksessä, että hiljainen tieto on kokemuksen kartuttama tietopohja taitavassa, intuitiivisessa toiminnassa näkyvälle hiljaiselle tietämiselle (48-53). Toom myös ottaa tarkasteluunsa erittäin tarpeellisena ulottuvuutena yksilöllisen ja yhteisöllisen aspektin hiljaiseen tietoon ja tietämiseen ja kokoaa ne yhteen kuvioon (54).

Toomin artikkeli tarjoaa tälle kirjalle riittävän käsitteellisen 
selvyyden hiljaisen tiedon ja tietämisen vaikeille ja monimutkaisille käsitteille. Kuitenkaan vuosikirjan muissa artikkeleissa ei ole lähdetty yhtenäisestä hiljaisen tiedon ja tietämisen määritelmästä, vaan kirjoittajat käyttävät molempia tai toista näistä käsitteistä omista lähtökohdistaan nojautuen pääasiassa Polanyin kirjoituksiin. Nimenomaan hiljaisen tiedon ja tietämisen kaltaisen naturalististen, vailla täsmällistä viittausalaa olevien käsitteiden kohdalla olisi oltava tarkkana, kun vertaillaan eri kirjoittajien niiden avulla saamia tuloksia. Käsitteen määrittely vaikuttaa lähes huomaamatta siihen, miten hiljaista tietoa voidaan tehdä näkyväksi, siirtää ja tunnistaa tai tunnustaa. Määritelmällisistä epäselvyyksistä aiheutuu joitakin ristiriitaisuuksia, kun artikkeleita lukee suhteessa toisiinsa.

\section{Hiljainen tieto ja kokemuksen siirto}

Hiljaisen tiedon ja tietämisen representoituminen ja niiden ilmaiseminen sanallisesti on tärkeä ongelma määritelmällisissä epäselvyyksissä. Suuri osa alueen tutkimuksellisista sovelluksista pyrkii saattamaan hiljaisen tiedon näkyväksi tavalla tai toisella. Hiljaisen tiedon tutkimisessa ei ole syytä lähteä siitä ääripäästä, että vain kielen avulla kokemuksen on mahdollista esiintyä (226-227), sillä kokemus voi ilmetä myös eleistä, ilmeistä yms. habituaalisista, tutkimuksenkin avulla näkyväksi tehtävistä asioista.

Myöskään ei ole syytä omaksua kantaa, että hiljainen tieto kattaa tiedostetun osaamisen (321). Eihän tiedostettu osaaminen enää ole hiljaista tietoa, sen sijaan se voi olla esimerkiksi itsereflektio siitä.

Yksi esimerkki määritelmän vaikutuksesta tutkimuksessa käytettävään metodiin on käsitys, että hiljaista tietoa on myös sellainen tieto, joka tiedetään, mutta josta ei kerrota (235). Tämähän mahdollistaa hiljaisen tiedon julkituomisen haastattelujen avulla. Olisiko kyseessä hiljainen tieto toisenlaisen, esimerkiksi habituaalisen määritelmän kautta tulkittuna?

Kirjan lukemisen jälkeen ihmettelee, että usein korostettua hiljaisen tiedon ja tietämisen karttumisen kontekstuaalisuuden edellyttämää merkityksen ymmärtämistä (vrt. Wittgenstein) ei ole juurikaan hyödynnetty siten, että tutkijat olisivat käyttäneet tutkimusmetodinaan havainnoivaa tai etnografista otetta. Erilaisia "kevyitä” aineistonkeruun menetelmiä, kuten kyselyitä ja haastatteluja sen sijaan on käytetty. Viitatut Nonaka ja Takeuchi (1995) kuitenkin korostavat yhteisen kokemuspohjan ja ymmärtämisen tärkeyttä hiljaisen tiedon sisältöjen jakamisessa. Teorialähtöistä havainnointia eivät ole harrastaneet muut kuin Toom väitöskirjatyöhönsä perustuvassa artikkelissa (163-186), vaikka tämän metodin voisi sanoa olevan uskollisempi hiljaisen tiedon/tietämisen käsitteelle kuin heti alkuunsa symbolisten representaatioiden puolelle menevät kielelliset aineistonkeruumenetelmät.

Tästä on vain lyhyt matka hiljaisen tiedon ja tietämisen tutkimisen peruskysymykseen, eli onko kirjassa tutkittu Hiljainen tieto - sanallistettu ilmiö - todellakin hiljaista tietoa. Metoditason kehitykseen pohdinta ei ole juurikaan vienyt.

Hiljaisen tiedon ilmiö ei ole neutraali siinä mielessä, että sen hankkiminen on yksilölle pitkän työssäoloajan tulosta ja nykyisenä tietointensiivisenä aikana ehkä tärkein pääoman muoto. Siksi olisikin naiivia kuvitella, että esimerkiksi mentorointikäytännöt olisivat yhtä hyvin toimivia kuin artikkelissa "Hiljainen tieto, mentorointi ja vertaistuki" (203-220) esitetään. Tämä on onneksi huomattu kirjan muissa artikkeleissa, joissa todetaan mm., että kokemukseen perustuvan osaamisen jakaminen työyhteisöissä ei ole ongelmatonta, tietoa salataan ja pantataan toisilta ja tieto voi toimia vallan välineenä (255, 269, 313).

Kirjassa on erittäin ansiokkaita artikkeleita, kuten esimerkiksi edellä mainitut Toomin artikkelit, Susanna Paloniemen hiljaisen tiedon jakamisen edellytyksiä pohtiva artikkeli (255-274) ja Tua Haldin-Herrgårdin ja Petri Salon erilaisia hiljaisen tiedon tutkimisen metodologioita esittävä artikkeli (277-299). Kaiken kaikkiaan kirjoittajat tuovat esille hyvin monipuolisen kavalkadin hiljaisen tiedon käsitteen erilaisista käyttötavoista.

Teos on varmasti monille lukijoille hyödyllinen katsaus erilaisiin mahdollisuuksiin lähestyä hiljaisen tiedon ja tietämisen käsitettä ja niiden tutkimisen tapoja. Teos on tarpeellinen kokoava lisä hiljaisen tiedon tutkimuksen karttuvaan kotimaiseen kirjallisuuteen. Ehkä hiljaisen tiedon käsitteen moninaisuuskin saavuttaa pikku hiljaa lakipisteensä ja tämänkaltaisten teosten kautta sen fokus alkaa palvella tutkimusta entistä paremmin teoreettisesti ja metodologisesti. 